\title{
Unconventional machining method for enhancing the durability of tools and strength of the speci- mens bonded
}

Assoc. Prof. Aleksandar Makedonski, MSc., Ph.D., D.Sc., Department of Manufacturing Technology and Machine Tools, Faculty of Machine Technology, Technical University of Sofia, 8”St.K1.Ohridski”Blvd., 1000 Sofia, Bulgaria. makedonski@tu-sofia.bg

The article presents the results from the application of a new method for raising the exploitation characteristics of metal-cutting tools, which includes preliminary combined magnetic field and ultrasound processing of the instrument. The indirect effect of the processing on the cutting force as well as on the roughness of the processed surface and on the wearing of the instruments during the drilling and milling processes has been studied. Demonstrated the effectiveness of the method on shear strength of the metal samples bonded

Key words: magnetic-ultrasound, wear-resistance, dependent variables, shear strength

\section{References}

[1] MAKEDONSKI A. (1991). Improving the durability of cutting tools by pre-energy impacts. / Dissertation for the degree - Dr., Sofia.

[2] MAKEDONSKI A. (2000). Physico-chemical phenomena and mechanism of hardening treated surfaces in the combined electro-processing. In: Proceedings of VI Konferenija naukowo-techniczna EM'2000 (Electromachining), Budgoszcz-Wenecja, Polska, p.p.97-104.

[3] MAKEDONSKI A., J. IVANOVA (2002). Methods for investigation of surface properties in carbon steels after combined electrophysical treatment. In: Proceedings of 2-nd Asia-pasific forum of Precision surface finishing and deburring technology, Seul,Korea, p.p.258-264.

[4] MAKEDONSKI A. (2006) The relationship between ultrasound combined magnetic effect, the internal energy of instrumental materials and their durability. In: Proceedings of $7^{\text {th }}$ IC „Advanced manufacturing operations-AMO”, Sozopol,Bulgaria, p.p.52-57.

[5] MAKEDONSKI A. (2005). Electrophisical technology to improve durability of ferromagnetic materials / Dissertation for the degree -Dr.Sc.techn., Sofia.

[6] ZIAD NABIH ABDOU. Experimentální výzkum šroubovitých vrtáků, Diplomová práce, ČVUT-Fakulstrojní, Praha 2007.

[7] MAKEDONSKI A., B. MAKEDONSKI, I. VILCEK (2009). Influence of the combined electrophisical treatment of the principal dependent variables during milling. In: Proceedings of IX ${ }^{\text {th }}$ IC “Advanced materials and operations-AMO", Kranevo, Bulgaria, vol.3, p.p.571-577.

[8] MAKEDONSKI A., I. VILCEK, B. MAKEDONSKI. (2009). Влияние совместной электрофизической обработки на зависимые переменные процесса фрезование сталь X155. In: Proceedings of $\mathrm{X}^{\text {th }}$ IC “Technologia”, Bratislava, Slovak.Rep., p.p.188-193.

[9] MAKEDONSKI A., B. MAKEDONSKI, I. VILCEK (2010). Effect of the combined electrophisical processing of process dependent variables during the milling. Of D2 steel. In: Journal AMO "Advanced materials and operations", Publisher AMO Society, Sofia, Bulgaria, vol.2, p.p.12-17. 